\title{
Respiratory hazards in hard metal workers: a cross sectional study
}

\author{
C MEYER-BISCH,' Q T PHAM, J-M MUR, ' N MASSIN,' J-J MOULIN,' \\ D TECULESCU, ${ }^{2}$ B CARTON, ' F PIERRE, ' ${ }^{\prime}$ F BARUTHIO'
}

From the INRS (French National Institute for Occupational Safety and Health) ${ }^{1}$ and INSERM (French National Institute for Medical Research U 115), ${ }^{2}$ Vandoeuvre les Nancy, France

ABSTRACT A cross sectional study was conducted on 513 employees at three hard metal plants: $425^{\circ}$ exposed workers ( 351 men, 74 women) and 88 controls (69 men, 19 women). Cough and sputum were ${ }^{3}$ more frequent in workers engaged in "soft powder" and presintering workshops compared with. controls $(12.5 \%$ and $16.5 \% v 3.5 \%)$. Spirometric abnormalities were more frequent among women in $n_{\dot{\omega}}^{\mathcal{G}}$ sintering and finishing workshops compared with control women $(56.8 \% v 23.8 \%)$ and abnormalities of carbon monoxide test were more frequent in exposed groups than in controls; this difference was은 more pronounced in women $(31.4 \% v 5.6 \%)$ than in men $(18.5 \% v 13 \%)$. No significant correlationwas observed between duration of exposure and age adjusted lung function tests. Slight abnormalities 3 of chest radiographs $(0 / 1,1 / 1$ according to ILO classification) were more frequent in exposed ment $<$ than controls $(12.8 \% v 1.9 \%)$ and mostly in soft powder workers. In subjects with abnormal chest $\vec{\infty}$ radiographs $\mathrm{FVC}, \mathrm{FEV}_{1}$ and carbon monoxide indices (fractional uptake of $\mathrm{CO}$ or $\mathrm{CO}$ transfer index $\oplus$ or both) were lower compared with those with normal chest radiographs. Although relatively mild, the clinical, radiological, and functional abnormalities uncovered call for a regular supervision of workers exposed to hard metal dust.

The industrial use of hard metal tools began in Germany in 1922. Owing to their hardness and resistance to wear and high temperatures they are used to make cutting tools, drill tips, and armament components. Their qualities are due mainly to tungsten carbide which, with cobalt (Co), constitutes the essential part of this alloy. They are produced according to the powder metallurgy technique in specialised factories in relatively large quantities (in France $\mathbf{3 0 0}$ tons a year at present).

About 20 years later, hard metals were suspected of being responsible for bronchopulmonary disorders, first in Germany, then in the other industrialised countries. Despite a certain heterogeneity of the symptoms and signs, the condition progresses towards a diffuse pulmonary fibrosis and leads to severe respiratory insufficiency. Except for sporadic case reports, the frequency and intensity of clinical and functional respiratory disorders which can be observed among a group of workers exposed to hard metal dust are not well known. Thus a cross sectional survey was conducted among a group of $\mathbf{4 2 5}$ workers exposed to hard metal dusts and of 88 controls who worked in three factories.

Accepted 9 May 1988

\section{Material and methods}

HARD METAL PRODUCTION PROCESS

The different stages of the hard metal production? process are summarised in fig 1 . The first stage of the process is the mixing of fine powders of tungsten carbide and carbides of other metals (such as titanium, $\frac{\mathbb{S}}{3}$ tantalium, niobium), and cobalt (10-30\%). In these working places dust concentrations may sometimes 3 . exceed 20 times the threshold limit values prescribed in the United States, especially during screening and₹ bagging operations. Raw pieces (lozenge shaped) are $\mathrm{O}$ obtained by pressing the powder into a mould. The hazards depend to a large extent on the working habitso of the operators and the efficiency of the exhaust ventilation. The powder may also be tightly com- $\sigma$ pressed at high temperature in isostatis presses (4 tons/ $N$ $\mathrm{cm}^{2}$ ) to form blocks which, after having been baked at $800^{\circ} \mathrm{C}$ (presintering) have the consistency of chalk ${ }^{\omega}$ (soft carbide). The next stage (forming) consists of cutting up the presintered blocks into pieces with the required shape. This stage also involves inhalation of dust since $20-40 \%$ of the initial block mass can be recovered in the form of waste and particles. The pieces are then baked at $1500^{\circ} \mathrm{C}$ (temperature of cobalt $\overrightarrow{\mathrm{D}}$ fusion) in oxygen free furnaces (sintering). The last $\frac{\rho}{\Phi}$ 


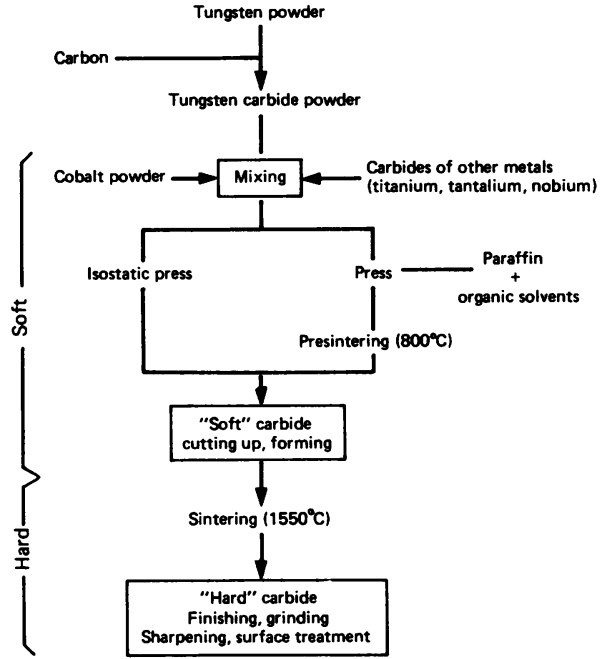

Fig 1 Steps of manufacture.

step is the finishing which is essentially rectification, grinding, sharpening with diamond tools, with or without cutting fluids.

The study was conducted in three factories where all the different stages of production mentioned were followed. In these factories all the production and maintenance workers (exposed groups) present in the factory for at least one year were invited to participate in the survey. The control group (not exposed) were workers from mechanical workshops and from warehouse and shipping departments. Altogether 425 subjects ( 351 men, 74 women) who constituted the exposed groups and 88 (69 men, 19 women) the control group were examined.

\section{TESTS}

The survey included:

$A$ questionnaire on respiratory and allergy symptoms (derived from that of the Medical Research Council with additional questions on smoking habits, occupation history, and occupational hazards).
Clinical examination - Chest and heart auscultation and measurement of systemic blood pressure.

Steady state carbon monoxide test - (Transfer test C mini-Morgan) with calculation of fractional uptake of $\mathrm{CO}(\mathrm{FuCO})$, partial fractional alveolocapillary uptake (FuaCO), and $\mathrm{TCO} / \mathrm{ml} / \mathrm{min} /$ torr; predicted values were those of Bates and colleagues. ${ }^{1}$

Single breath oxygen test-(Nitrogen washout, Hewlett-Packard equipment) with calculation of slope of phase III $\left(\triangle N_{2}\right)$ and ratio of closing volume/vital capacity $(\mathrm{CV} / \mathrm{VC})$. Predicted values were those of Buist and Ross. ${ }^{2}$

Single breath carbon monoxide test - (TCO single breath Hewlett-Packard system) with calculation of $\mathrm{TCO} / \mathrm{ml} / \mathrm{min} /$ torr, total lung capacity (TLC), and Krogh factor $\left(\mathrm{TCO}_{\mathrm{sb}} / \mathrm{TLC}\right)$. Predicted values were those of Cotes and Hall. ${ }^{3}$

Forced expiration test: flow volume curves-(Pulmonary calculator Hewlett-Packard system); three curves were required of which forced vital capacity (FVC), forced expiratory volume in one second $\left(F V_{1}\right), F E V_{1} / F V C$ ratio, and the mean expiratory flows, $\mathrm{FEF}_{25-75}$ and $\mathrm{FEF}_{75-85}$ were calculated on the "best" curve (largest sum FVC + FEV ; American Thoracic Society criteria). ${ }^{4}$ Predicted values were those of Morris and colleagues. ${ }^{5}$

Test of bronchial hyperreactivity-An aerosol of acetylcholine (concentration: $100 \mathrm{mg} / \mathrm{l}$ ) delivered by a Gauchard AMP 7 (20 litres air/min) nebuliser was inhaled for three minutes by the subject through a face mask and three flow volume curves were repeated. If the subjects had a history of asthma or an obstructive syndrome an aerosol of Salbutamol was used (4 puffs of Ventolin) instead of acetylcholine, trying to induce a bronchodilatation. Bronchial hyperreactivity was defined as a change after challenge of at least $10 \%$ of $\mathrm{FEV}_{1}$ or of at least $15 \%$ for $\mathrm{FEF}_{25-75}$, or both.

$A$ pulmonary radiograph (size $10 \times 10 \mathrm{~cm}$ ), read independently by two chest physicians; only reticular shadows and small rounded opacities were classified using the 12 point scale of increasing profusion described by the International Labour Office. ${ }^{6}$

Urine samples (about $250 \mathrm{ml}$ ) were collected at the

Table 1 Arithmetic mean values of total dust and cobalt measured by personal samplers worn during a workshift

\begin{tabular}{|c|c|c|c|c|c|c|}
\hline \multirow[b]{2}{*}{ Workshop } & \multicolumn{2}{|l|}{ Factory 1} & \multicolumn{2}{|l|}{ Factory 2} & \multicolumn{2}{|l|}{ Factory 3} \\
\hline & $\begin{array}{l}\text { Total dust } \\
\left(\mathrm{mg} / \mathrm{m}^{3}\right)\end{array}$ & $\begin{array}{l}\text { Cobalt } \\
\left(\mu \mathrm{g} / \mathrm{m}^{3}\right)\end{array}$ & $\begin{array}{l}\text { Total dust } \\
\left(\mathrm{mg} / \mathrm{m}^{3}\right)\end{array}$ & $\begin{array}{l}\text { Cobalt } \\
\left(\mu \mathrm{g} / \mathrm{m}^{3}\right)\end{array}$ & $\begin{array}{l}\text { Total dust } \\
\left(\mathrm{mg} / \mathrm{m}^{3}\right)\end{array}$ & $\begin{array}{l}\text { Cobalt } \\
\left(\mu g / m^{3}\right)\end{array}$ \\
\hline $\begin{array}{l}\text { Powder } \\
\text { Presses } \\
\text { Forming } \\
\text { Finishing }\end{array}$ & $\begin{array}{l}7.80 \\
0.63 \\
1.08 \\
0.70\end{array}$ & $\begin{array}{r}117 \\
30 \\
160 \\
30\end{array}$ & $\begin{array}{r}13 \cdot 10 \\
0 \cdot 54 \\
0 \cdot 81 \\
2 \cdot 37\end{array}$ & $\begin{array}{r}272 \\
50 \\
110 \\
95\end{array}$ & $\begin{array}{l}2.50 \\
1.58 \\
1 \cdot 10 \\
2.59\end{array}$ & $\begin{array}{r}45 \\
220 \\
60 \\
210\end{array}$ \\
\hline
\end{tabular}

TLV-TWA $=5 \mathrm{mg} / \mathrm{m}^{3}$ for total dust; TLV-TWA $=50 \mu \mathrm{g} / \mathrm{m}^{3}$ for cobalt dust. TLV-TWA (threshold limit value - time weighted average) are fixed by the American Conference of Governmental Industrial Hygienists. 


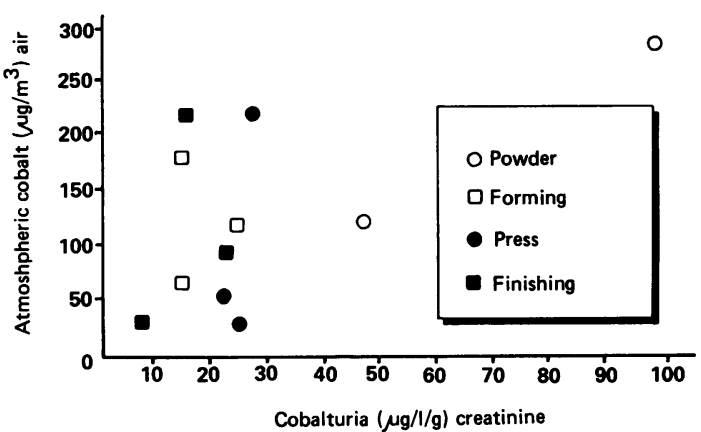

Fig 2 Mean values of airborne cobalt and cobalturia. Atmospheric cobalt is related to urinary cobalt content for a group of workers at four workplaces. Individual results are plotted on figure. Personal samplers were carried for four hours and urine was collected at end of workshift.

end of worktime every day except for Friday when the samples were taken at noon. From each sample, $30 \mathrm{ml}$ was dropped into a tube and immediately stabilised with $300 \mu \mathrm{l}$ of hydrochloric acid; $5 \mathrm{ml}$ was saved into another tube. All the samples were then frozen. At the laboratory, the $30 \mathrm{ml}$ tube was used to fix the quantity of cobalt by electrothermal atomic absorption spectrometry and the $5 \mathrm{ml}$ tube for determination of creatinine.

Collection of dusts in the workshops was carried out with fixed and personal samplers. Size of particles and nature of dust (mainly cobalt and tungsten) were determined.

Statistical methods used to compare the results of exposed workers and controls were analysis of variance ( $F$ test) and $t$ test for independent quantitative variables and $\chi^{2}$ test with Yates's correction when necessary.

\section{Results}

Total dust measurements (table 1) showed that the most polluted workshops were the powder work- $\frac{2}{2}$ shops, ${ }^{7}$ where the mean values exceeded the limit value $\stackrel{\Phi}{ }$ $\left(\mathrm{TLV}=5 \mathrm{mg} / \mathrm{m}^{3}\right.$ ) fixed by the American Conference of Governmental Industrial Hygienists (ACGIH) in two factories. The mean values of cobalt dust exceeded $\overline{0}$ also the TLV $\left(50 \mu \mathrm{g} / \mathrm{m}^{3}\right)$ in these workshops and in the $\frac{\bar{\sigma}}{\sigma}$ forming workshops. In the third factory high values of $\overline{\bar{c}}$ cobalt dust were observed in a press workshop and in $\widehat{\nabla}$ some finishing workshops. The urinary cobalt content reflected rather weakly the amount of dust in the ${ }^{\infty}$ workshops (fig 2). Cobalturia on Monday and Friday $\overrightarrow{0}$ was lower than for the other days as factories stopped $\vec{\overrightarrow{ }}$ during the weekend and on Friday collections were $\omega_{\sigma}$ made at noon.

To simplify the analysis, exposed workers in the $\frac{\mathbb{D}}{3}$ powder, press, and furnace workshops formed one group, the "soft group", whereas the "hard group" or was composed of sintering and finishing workers. $\omega$ Taking into account the maintenance workers and the $\mathrm{N}$ controls, four groups were obtained:

\begin{tabular}{|c|c|c|c|}
\hline & & Men & Women \\
\hline Group 0 & Controls & 69 & 19 \\
\hline Group & Soft & 143 & 34 \\
\hline Group 2 & Hard & 156 & 40 \\
\hline Group 3 & Maintenance & 52 & - \\
\hline
\end{tabular}

Table 2 summarises the groups' characteristics. As age and height differed from one group to another, the comparisons of pulmonary function values are based on percentage of predicted values. There were more smokers in the exposed group $(52.5 \%)$ than in the $\frac{\circ}{\Phi}$ control group (35.7\%); the average current consumption was the same in both groups $(17 \mathrm{~g} /$ day $)$. Smokers and non-smokers were compared separately in the different groups.

\section{RESPIRATORY SYMPTOMS}

Cough and sputum were more frequent in the exposed $\stackrel{\oplus}{3}$ groups than the controls, but the difference was only significant for the men in group 1 and for women in group 2 ( $\mathrm{p}<0.05)$. Among non-smoking men, these

Table 2 Biometric characteristics and smoking habits

\begin{tabular}{|c|c|c|c|c|c|c|c|}
\hline & \multicolumn{4}{|l|}{ Men } & \multicolumn{3}{|l|}{ Women } \\
\hline & $\begin{array}{l}\text { Controls } \\
(n=69)\end{array}$ & $\begin{array}{l}\text { Group I } \\
(n=143)\end{array}$ & $\begin{array}{l}\text { Group } 2 \\
(n=156)\end{array}$ & $\begin{array}{l}\text { Group } 3 \\
(n=52)\end{array}$ & $\begin{array}{l}\text { Controls } \\
(n=19)\end{array}$ & $\begin{array}{l}\text { Group I } \\
(n=34)\end{array}$ & $\begin{array}{l}\text { Group 2 } \\
(n=40)\end{array}$ \\
\hline $\begin{array}{l}\text { Mean age }(\mathrm{y}) \\
\text { Mean height }(\mathrm{cm}) \\
\text { Mean weight }(\mathrm{kg}) \\
\text { Mean duration of } \\
\text { employment }(\mathrm{y})\end{array}$ & $\begin{array}{r}38 \cdot 9 \\
171 \cdot 8 \\
73 \cdot 7 \\
12 \cdot 03\end{array}$ & $\begin{array}{l}39 \cdot 6 \\
168 \cdot 5^{* * *} \\
70 \cdot 7^{*} \\
13 \cdot 97\end{array}$ & $\begin{array}{r}37 \cdot 7 \\
170 \cdot 5 \\
72 \cdot 3 \\
13 \cdot 12\end{array}$ & $\begin{array}{l}44 \cdot 2^{* * *} \\
171 \cdot 5 \\
72 \cdot 5 \\
17 \cdot 83^{* * * *}\end{array}$ & $\begin{array}{r}42 \cdot 7 \\
160 \cdot 9 \\
60 \cdot 2 \\
13 \cdot 39\end{array}$ & $\begin{array}{c}42 \cdot 9 \\
155 \cdot 7^{*} \\
59 \cdot 7 \\
14 \cdot 21\end{array}$ & $\begin{array}{r}39.9 \\
157.6 \\
60.5 \\
13.49\end{array}$ \\
\hline $\begin{array}{l}\text { Smoking habits: } \\
\text { Non-smokers (\%) } \\
\text { Ex-smokers (\%) } \\
\text { Smokers (\%) }\end{array}$ & $\begin{array}{l}42 \\
21 \cdot 7 \\
36 \cdot 2\end{array}$ & $\begin{array}{l}22 \cdot 4^{* *} \\
16 \cdot 8 \\
60 \cdot 8^{* * *}\end{array}$ & $\begin{array}{l}39 \cdot 7 \\
14 \cdot 1 \\
46 \cdot 2\end{array}$ & $\begin{array}{l}26 \cdot 9 \\
23 \cdot 1 \\
50\end{array}$ & $\begin{array}{c}89 \cdot 9 \\
11 \cdot 1 \\
0\end{array}$ & $\begin{array}{c}70 \cdot 6 \\
2.9 \\
26.5^{*}\end{array}$ & $\begin{array}{l}67 \cdot 6 \\
10 \cdot 8 \\
21 \cdot 6^{*}\end{array}$ \\
\hline Comparisons are mad & een expos & up and con & $\left({ }^{*} p<0.05\right.$ & $p<0.01 ;$ & $<0.001)$ & & \\
\hline
\end{tabular}



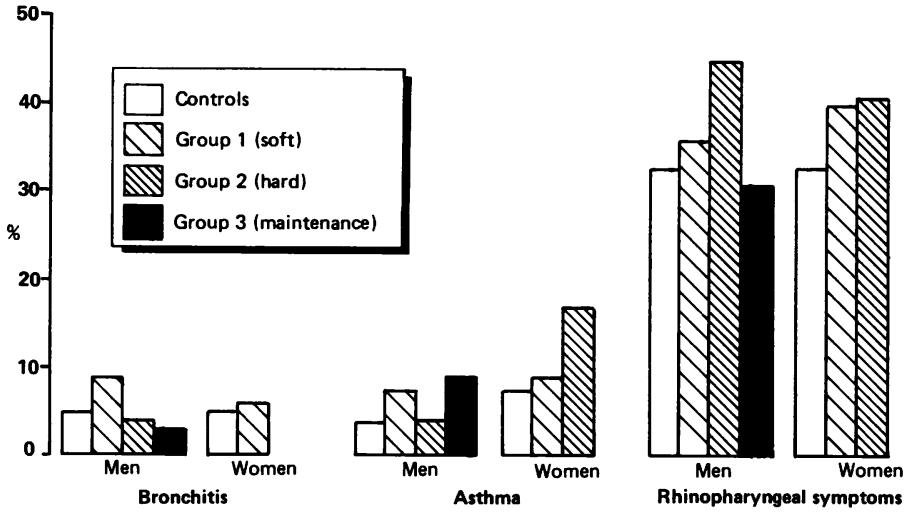

Fig 3 Clinical symptoms.

symptoms were twice as frequent in exposed workers than the controls. Dyspnoea (grade 1 or 2 according to Fletcher classification ${ }^{8}$ ) was rare, except in the presin-

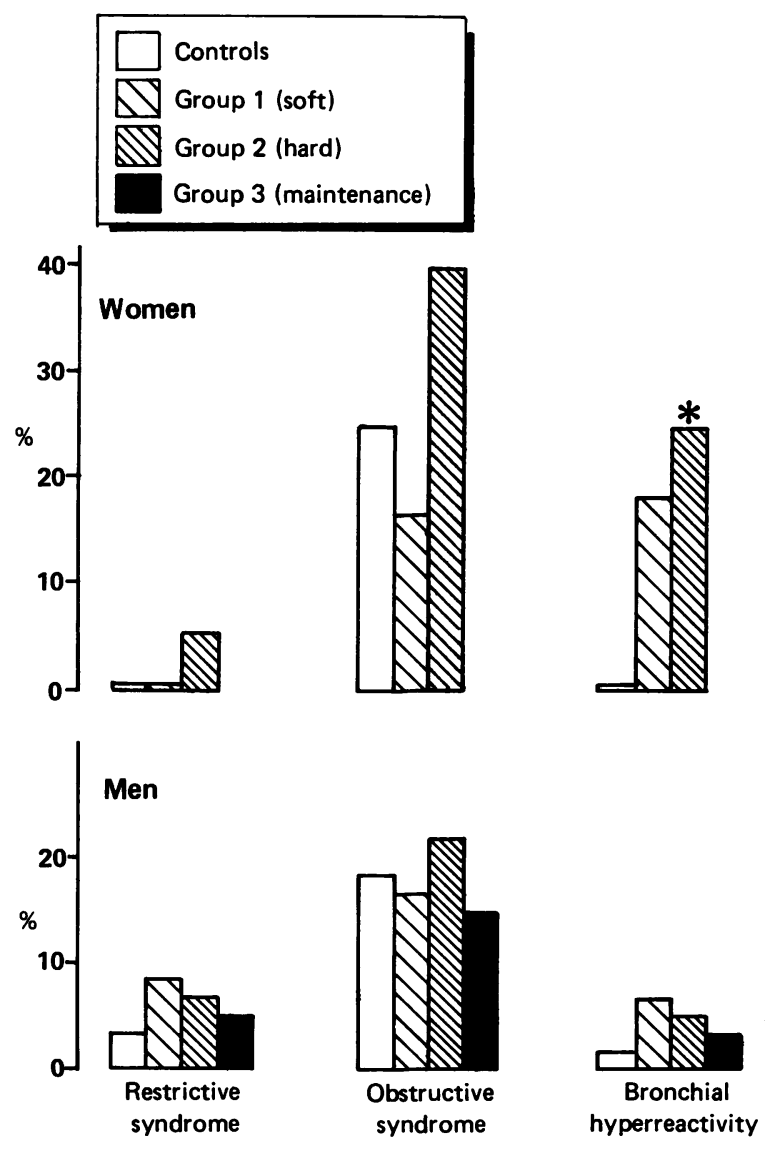

Fig 4 Prevalence of functional abnormalities - spirometry. *Chi-squared test between the group and controls $p<0.05$. tering subgroup where it was reported by $16 \%$ of the men versus $2.9 \%$ of the controls.

Chronic bronchitis (according to the ATS criteria') was more frequent in non-smokers of group 1 than the controls. Asthma (according to the ATS criteria) was rare in men of all groups. It was slightly more frequent among the women of group 2 than the controls $(16.2 \%$ $v 5.6 \%)$. Pulmonary adventitious sounds were slightly more frequent in exposed than in non-exposed subjects. Rhinorrhoea or sinusitis were reported by about a third of the subjects, in both exposed and nonexposed groups (fig 3).

\section{LUNG FUNCTION TESTS}

Spirometry

A comparison of the groups was performed on the percentage of "abnormalities" and on the values of the pulmonary functional indices. In men the obstructive syndrome, defined as normal VC with $\mathrm{FEV}_{1}$ or MMEF less than $80 \%$ of the predicted values, seemed more related to smoking habits than to dust exposure. Among women, obstructive or restrictive syndromes (restrictive syndrome defined as VC and TLC below $80 \%$ of predicted values, with normal $\mathrm{FEV}_{\mathrm{i}} / \mathrm{VC}$ ratio) were more frequent in group 2 compared with controls $(56.8 \% v 23.8 \%-p<0.05)$. Bronchial hyperreactivity was also more frequent in this group (fig 4).

In men, smokers and non-smokers, the end expiratory flow $\left(\mathrm{FEF}_{75-85}\right)$ of group 1 was slightly lower than in controls but the difference was not significant. For the other indices of spirometry the mean values were similar for exposed and non-exposed groups (table 3).

\section{Diffusing capacity}

"Abnormalities" of steady state carbon monoxide uptake $\left(\mathrm{TCO}_{\mathrm{ss}}\right)$, defined as values of TCO indices below $90 \%$ of predicted values, were more often observed in exposed groups than in controls, more so 
Table 3 Pulmonary function (\% predicted) in various groups. Mean (standard deviations)

\begin{tabular}{|c|c|c|c|c|c|c|c|}
\hline & \multicolumn{4}{|l|}{ Men } & \multicolumn{3}{|l|}{ Women } \\
\hline & $\begin{array}{l}\text { Controls } \\
(n=69)\end{array}$ & $\begin{array}{l}\text { Group 1 } \\
(n=143)\end{array}$ & $\begin{array}{l}\text { Group } 2 \\
(n=156)\end{array}$ & $\begin{array}{l}\text { Group } 3 \\
(n=52)\end{array}$ & $\begin{array}{l}\text { Controls } \\
(n=17)\end{array}$ & $\begin{array}{l}\text { Group I } \\
(n=34)\end{array}$ & $\begin{array}{l}\text { Group } 2 \\
(n=40)\end{array}$ \\
\hline 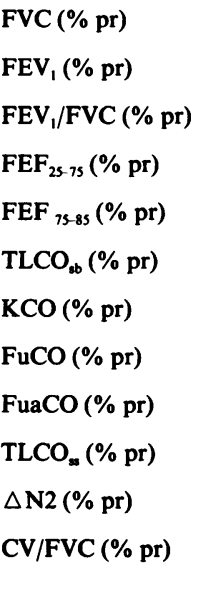 & $\begin{array}{c}104 \cdot 32 \\
(13 \cdot 51) \\
97 \cdot 50 \\
(13 \cdot 70) \\
90 \cdot 69 \\
(8.47) \\
71 \cdot 74 \\
(23.73) \\
78 \cdot 78 \\
(36 \cdot 37) \\
111 \cdot 40 \\
(17 \cdot 45) \\
101 \cdot 70 \\
(13.95) \\
103.41 \\
(9 \cdot 13) \\
95 \cdot 32 \\
(7 \cdot 45) \\
107.94 \\
(7.45) \\
91 \cdot 53 \\
(64.70) \\
113.69 \\
(49 \cdot 04)\end{array}$ & $\begin{array}{c}103.62 \\
(14 \cdot 71) \\
96.54 \\
(15 \cdot 25) \\
90 \cdot 13 \\
(9.80) \\
72.90 \\
(24.42) \\
75.06 \\
(33.62) \\
109.85 \\
(18.99) \\
100.67 \\
(17.60) \\
100.68 * \\
(10.60) \\
91.05 * * * \\
(8 \cdot 13) \\
92.95 * * * \\
(8.13) \\
103.41 \\
(109.90) \\
115 \cdot 16 \\
(44.91)\end{array}$ & $\begin{array}{c}103.68 \\
(11 \cdot 73) \\
97 \cdot 36 \\
(12 \cdot 83) \\
91 \cdot 12 \\
(9.66) \\
75.44 \\
(23 \cdot 28) \\
81 \cdot 19 \\
(35.09) \\
112.91 \\
(19.36) \\
101 \cdot 73 \\
(16.32) \\
101.04 \\
(9.23) \\
92.49 * * \\
(8.09) \\
91.05 * * * \\
(8.09) \\
86.77 \\
(69.58) \\
108 \cdot 60 \\
(42.88)\end{array}$ & $\begin{array}{c}102 \cdot 60 \\
(11.85) \\
97 \cdot 11 \\
(14 \cdot 15) \\
91 \cdot 53 \\
(7.95) \\
71 \cdot 22 \\
(20.96) \\
74 \cdot 48 \\
(28.64) \\
112.21 \\
(20.23) \\
103.71 \\
(18.53) \\
100.47 \\
(9.59) \\
94.51 \\
(8.85) \\
94.51 \\
(8 \cdot 85) \\
102.38 \\
(89.65) \\
110.96 \\
(34.21)\end{array}$ & $\begin{array}{c}108 \cdot 50 \\
(11.67) \\
99.61 \\
(16.74) \\
88.66 \\
(12.49) \\
75.87 \\
(33.35) \\
77.31 \\
(35.54) \\
97.01 \\
(11.09) \\
98.65 \\
(11.75) \\
100.90 \\
(5.48) \\
91.10 \\
(4.97) \\
79.12 \\
(8.70) \\
96.45 \\
(47.03) \\
96.38 \\
(31.24)\end{array}$ & $\begin{array}{l}106 \cdot 18 \\
(12 \cdot 61) \\
100 \cdot 65 \\
(13 \cdot 98) \\
91 \cdot 51 \\
(7 \cdot 21) \\
78 \cdot 62 \\
(24 \cdot 11) \\
76 \cdot 86 \\
(32 \cdot 82) \\
105 \cdot 76^{*} \\
(15 \cdot 87) \\
109 \cdot 13^{*} \\
(19 \cdot 45) \\
103 \cdot 15 \\
(12 \cdot 53) \\
86.94^{* *} \\
(7 \cdot 12) \\
90 \cdot 12 \\
(28 \cdot 11) \\
82 \cdot 38 \\
(58 \cdot 59) \\
97 \cdot 26 \\
(41 \cdot 67)\end{array}$ & $\begin{array}{c}104 \cdot 01 \\
(11 \cdot 39) \\
94.93 \\
(13 \cdot 76) \\
88 \cdot 14 \\
(9 \cdot 12) \\
71 \cdot 84 \\
(20 \cdot 02) \\
69 \cdot 34 \\
(29 \cdot 31) \\
98 \cdot 72 \\
(16 \cdot 71) \\
103 \cdot 75 \\
(17 \cdot 37) \\
100 \cdot 19 \\
(8.85) \\
86.55 * * \\
(6.93) \\
83.87 \\
(22.70) \\
106.68 \\
(73.29) \\
87.47 \\
(38.68)\end{array}$ \\
\hline
\end{tabular}

Comparisons are made between exposed group and controls $\left({ }^{*} p<0.05 ;{ }^{* *} p<0.01 ;{ }^{* *} p<0.001\right)$.

in women $(21.4 \% v 5.6 \%)$ than in men $(18.5 \% v 13 \%)$ (fig 5). The comparison of means (table 3 ) showed significant differences of the alveolar capillary fractional uptake (FuaCO) which was lower in groups 1

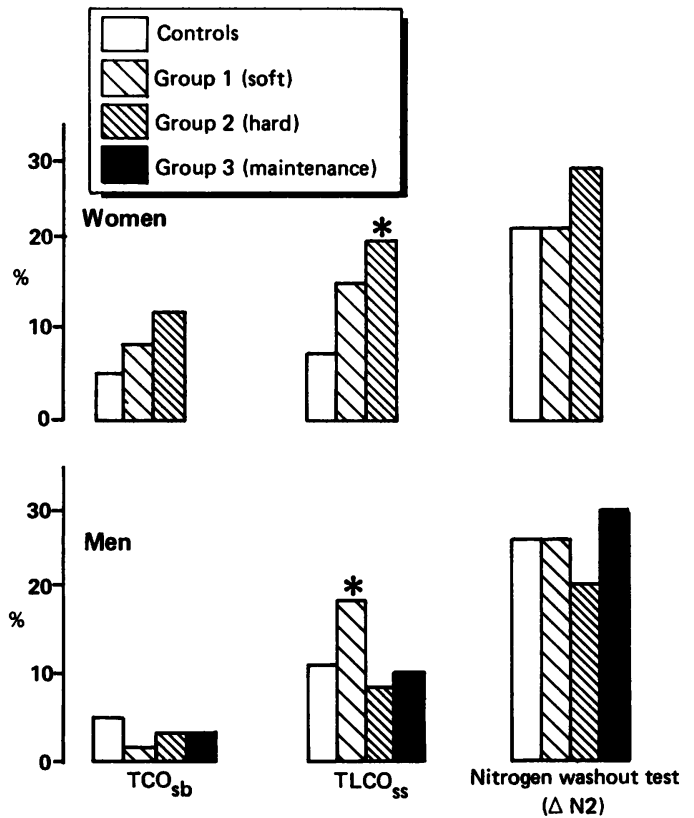

Fig 5 Prevalence of functional abnormalities - $\mathrm{CO}$ and $\mathrm{N2}$ tests. ${ }^{*}$ Chi-squared test between group and controls $p<0.05$. and 2 for men and women compared with controls. The same was observed in men for TCO steady state. When smoking habits were taken into account, FuaCO was also lower in groups 1 and 2 compared with controls among non-smokers, whereas among smokers $\mathrm{TCO}_{\mathrm{ss}}$ was lower in these groups compared with controls (table 4).

Single breath oxygen test

The mean values of slope of phase III and of CV/VC in this study did not differ significantly between exposed and non-exposed groups.

\section{Duration of exposure}

Partial correlations were calculated between duration of work in exposed workers and functional indices: $\mathrm{FEF}_{25-75}, \mathrm{FEF}_{75-85}$, slope of phase III, TLCO ${ }_{3 b}, \mathrm{KCO}$, $\mathrm{TLCO}_{\text {se }}$, and FuaCO. Computation of partial correlation coefficients ${ }^{10}$ eliminated the effects of age, which is highly associated with duration of exposure. Using this method, no significant correlation was observed between functional indices and duration of exposure.

Chest radiographs and pulmonary function tests

Particular attention was given to the relation between radiographic abnormalities and function tests. Pulmonary radiographs were read by two chest physicians separately and independently of each other, the final score being obtained by consensus. No major abnormalities were seen in the sample of the survey which excluded subjects with non-occupational pulmonary 
Table 4 Pulmonary function (\% predicted) in various groups. Mean (standard deviations)

\begin{tabular}{|c|c|c|c|c|c|c|c|c|}
\hline & \multicolumn{4}{|c|}{ Non-smokers } & \multicolumn{4}{|l|}{ Smokers } \\
\hline & $\begin{array}{l}\text { Controls } \\
(n=29)\end{array}$ & $\begin{array}{l}\text { Group } 1 \\
(n=32)\end{array}$ & $\begin{array}{l}\text { Group 2 } \\
(n=62)\end{array}$ & $\begin{array}{l}\text { Group } 3 \\
(n=14)\end{array}$ & $\begin{array}{l}\text { Controls } \\
(n=25)\end{array}$ & $\begin{array}{l}\text { Group } 1 \\
(n=87)\end{array}$ & $\begin{array}{l}\text { Group 2 } \\
(n=72)\end{array}$ & $\begin{array}{l}\text { Group 3 } \\
(n=26)\end{array}$ \\
\hline FVC (\% pr) & $105 \cdot 96$ & $106 \cdot 76$ & $104 \cdot 53$ & $103 \cdot 58$ & $100 \cdot 80$ & $103 \cdot 02$ & $103 \cdot 16$ & $100 \cdot 80$ \\
\hline & $(12 \cdot 33)$ & $(17.62)$ & $(12 \cdot 11)$ & $(13.81)$ & $(12.02)$ & $(13 \cdot 30)$ & $(10.82)$ & $(12.58)$ \\
\hline $\mathrm{FEV}_{1}$ (\% pr) & $\begin{array}{l}101 \cdot 23 \\
(11 \cdot 74)\end{array}$ & $\begin{array}{l}100.93 \\
(15.46)\end{array}$ & $\begin{array}{l}100.68 \\
(13.22)\end{array}$ & $\begin{array}{l}101.91 \\
(14.39)\end{array}$ & $\begin{array}{l}94.02 \\
(11.92)\end{array}$ & $\begin{array}{l}95 \cdot 30 \\
(13.08)\end{array}$ & $\begin{array}{l}96 \cdot 15 \\
(10 \cdot 44)\end{array}$ & $\begin{array}{l}93 \cdot 18 \\
(15 \cdot 15)\end{array}$ \\
\hline $\mathrm{FEV}_{1} / \mathrm{FVC}(\% \mathrm{pr})$ & 92.75 & 91.54 & 93.39 & 95.08 & 90.67 & 89.61 & 90.50 & 89.45 \\
\hline $\mathrm{FEF}_{25-75}(\% \mathrm{pr})$ & $\begin{array}{l}(6 \cdot .92) \\
78.49\end{array}$ & $\begin{array}{l}(6 \cdot 19) \\
76.58\end{array}$ & $\begin{array}{l}(8.06) \\
80.41\end{array}$ & $\begin{array}{l}(5 \cdot 32) \\
80 \cdot 32\end{array}$ & $\begin{array}{l}(9.00) \\
71 \cdot 29\end{array}$ & $\begin{array}{l}(8 \cdot 71) \\
69.83\end{array}$ & $\begin{array}{l}(9 \cdot 43) \\
74 \cdot 14\end{array}$ & $\begin{array}{l}(9 \cdot 22) \\
65 \cdot 11\end{array}$ \\
\hline & $(19.62)$ & $(24.82)$ & $(21 \cdot 60)$ & $(16 \cdot 47)$ & $(24.61)$ & $(21.04)$ & $(24 \cdot 46)$ & $(22 \cdot 70)$ \\
\hline FEF $7585(\%$ pr $)$ & $\begin{array}{l}87 \cdot 18 \\
(31.45)\end{array}$ & $\begin{array}{c}80.53 \\
(35.89)\end{array}$ & $\begin{array}{c}87.64 \\
(36.93)\end{array}$ & $\begin{array}{c}85 \cdot 84 \\
(29 \cdot 29)\end{array}$ & $\begin{array}{r}82.64 \\
(34.52)\end{array}$ & $\begin{array}{c}72.01 \\
(31.59)\end{array}$ & $\begin{array}{r}79.61 \\
(34.29)\end{array}$ & $\begin{array}{l}71.21 \\
(29.52)\end{array}$ \\
\hline $\mathrm{TLCO}_{\mathrm{sb}}(\% \mathrm{pr})$ & $118 \cdot 14$ & $116 \cdot 85$ & 118.59 & $122 \cdot 17$ & $103 \cdot 24$ & $106 \cdot 33$ & 107.80 & 104.21 \\
\hline $\mathrm{KCO}(\% \mathrm{pr})$ & $\begin{array}{l}(13 \cdot 76) \\
107 \cdot 22\end{array}$ & $\begin{array}{l}(13.96) \\
106.64\end{array}$ & $\begin{array}{l}(16.73) \\
105.05\end{array}$ & $\begin{array}{l}(18 \cdot 76) \\
112 \cdot 21\end{array}$ & $\begin{array}{l}(18.41) \\
95 \cdot 30\end{array}$ & $\begin{array}{l}(19.93) \\
97.02\end{array}$ & $\begin{array}{c}(20 \cdot 50) \\
98.62\end{array}$ & $\begin{array}{l}(19 \cdot 74) \\
97 \cdot 37\end{array}$ \\
\hline (1) & (9.52) & (14.53) & (13.55) & (13.83) & $(15.53)$ & $(17 \cdot 60)$ & $(18.42)$ & $(19.02)$ \\
\hline FuCO (\% pr) & $\begin{array}{c}105.04 \\
(7.44)\end{array}$ & $\begin{array}{l}105 \cdot 20 \\
(10 \cdot 19)\end{array}$ & $\begin{array}{r}102 \cdot 16 \\
(8 \cdot 20)\end{array}$ & $\begin{array}{l}103.92 \\
(11.39)\end{array}$ & $\begin{array}{l}102.91 \\
(10.95)\end{array}$ & $\begin{array}{c}98.97 \\
(10.32)\end{array}$ & $\begin{array}{l}99 \cdot 61 \\
(10 \cdot 79)\end{array}$ & $\begin{array}{l}99 \cdot 65 \\
(9.65)\end{array}$ \\
\hline FuaCO (\% pr) & $\begin{array}{l}97.39 \\
(5.79)\end{array}$ & $\begin{array}{l}92.38 * * \\
(8.44)\end{array}$ & $\begin{array}{l}94.66^{*} \\
(6.02)\end{array}$ & $\begin{array}{l}97.34 \\
(9.67)\end{array}$ & $\begin{array}{l}92.95 \\
(8.96)\end{array}$ & $\begin{array}{r}90.14 \\
(8.12)\end{array}$ & $\begin{array}{l}90.22 \\
(8.81)\end{array}$ & $\begin{array}{l}93.14 \\
(8.49)\end{array}$ \\
\hline $\mathrm{TLCO}_{\mathrm{se}}(\% \mathrm{pr})$ & 110.65 & $100 \cdot 64$ & 102.67 & 116.84 & 108.65 & $88.96^{* * *}$ & $85 \cdot 73^{* * *}$ & 94.55 \\
\hline$\triangle \mathrm{N} 2(\% \mathrm{pr})$ & $\begin{array}{l}(20.70) \\
68.94\end{array}$ & $\begin{array}{c}(25 \cdot 46) \\
60 \cdot 16\end{array}$ & $\begin{array}{l}(27.82) \\
70.95\end{array}$ & $\begin{array}{c}(41.72) \\
67.09\end{array}$ & (28.78) & $\begin{array}{l}(24.93) \\
114.49\end{array}$ & $(22.72)$ & $(23.92)$ \\
\hline$\Delta \mathrm{N} 2(\mathrm{~F} \mathrm{pi})$ & $(43 \cdot 17)$ & $(36.98)$ & $\begin{array}{l}70.95 \\
(58.35)\end{array}$ & $\begin{array}{l}67.09 \\
(40.01)\end{array}$ & $\begin{array}{l}100.32 \\
(69 \cdot 70)\end{array}$ & $\begin{array}{l}114 \cdot 49 \\
(108 \cdot 71)\end{array}$ & $\begin{array}{l}103.29 \\
(81 \cdot 27)\end{array}$ & $(112 \cdot 72)$ \\
\hline CV/FVC (\% pr) & $\begin{array}{l}103 \cdot 79 \\
(28 \cdot 38)\end{array}$ & $\begin{array}{l}109 \cdot 28 \\
(41 \cdot 16)\end{array}$ & $\begin{array}{l}96.83 \\
(32.99)\end{array}$ & $\begin{array}{l}103 \cdot 79 \\
(24 \cdot 17)\end{array}$ & $\begin{array}{l}128.05 \\
(61.02)\end{array}$ & $\begin{array}{c}119.41 \\
(50 \cdot 30)\end{array}$ & $\begin{array}{l}116 \cdot 70 \\
(48 \cdot 96)\end{array}$ & $\begin{array}{c}108.43 \\
(30.40)\end{array}$ \\
\hline
\end{tabular}

Comparisons are made between exposed group and controls $\left({ }^{*} p<0.05 ;{ }^{* *} p<0.01 ;{ }^{* * *} p<0.001\right)$.

history. Minor abnormalities $(0 / 1,1 / 1$, according to the ILO classification ${ }^{6}$ ) were significantly more frequent in exposed men than in the controls $(12.8 \% v$ $1.9 \%-\mathrm{p}<0.05)$. In group 1 where the difference was the most significant $(p<0.001) 24 \%$ of the workers of the powder workshop and $19.5 \%$ of the press workshop had radiological abnormalities (fig 6). These differences were observed irrespective of the smoking habits. (For women, groups were too small for statistical comparison.)

Male subjects with abnormalities in chest radiographs were paired with subjects with a normal chest film, according to age, smoking habits, and duration and place of work, and their function tests were compared. So table 5 shows the functional data of 12 pairs from group 2 and 22 from group 1: FVC and $F_{E V}$, were significantly lower in the subjects with

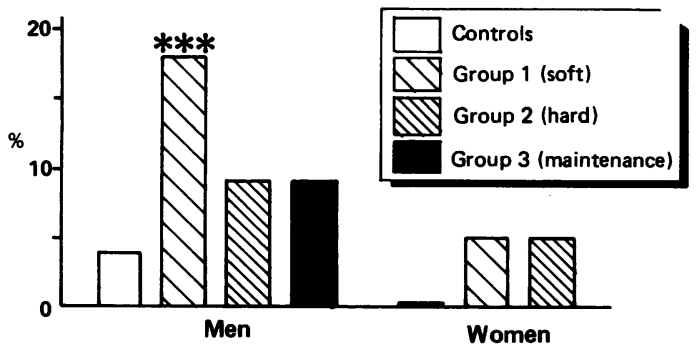

Fig 6 Pulmonary radiographic abnormalities. ***Chisquared test between the group and controls $p<0.001$.
Table 5 Pulmonary function (\% predicted) in matched pairs of workers with normal and abnormal chest radiographs (CR)

\begin{tabular}{|c|c|c|c|c|}
\hline & \multicolumn{2}{|c|}{ Group $1(n=22$ pairs $)$} & \multicolumn{2}{|c|}{ Group 2 ( $n=12$ pairs $)$} \\
\hline & CR normal & CR abnormal & CR normal & CR abnormal \\
\hline $\begin{array}{l}\text { FVC (\% pr) } \\
\text { FEV }_{1}(\% \mathrm{pr})\end{array}$ & $\begin{array}{l}110 \cdot 40^{*} \\
(17 \cdot 00) \\
101 \cdot 18^{*} \\
(16 \cdot 76)\end{array}$ & $\begin{array}{c}97.97 \\
(11.83) \\
90 \cdot 17 \\
(15.40)\end{array}$ & $\begin{array}{l}109 \cdot 02^{*} \\
(12 \cdot 24) \\
103 \cdot 81^{*} \\
(11 \cdot 51)\end{array}$ & $\begin{array}{l}98.94 \\
(8.87) \\
92.63 \\
(7.26)\end{array}$ \\
\hline 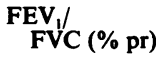 & $\begin{array}{c}88.81 \\
(8.72)\end{array}$ & $\begin{array}{l}88.73 \\
(9.98)\end{array}$ & $\begin{array}{l}92.32 \\
(8.35)\end{array}$ & $\begin{array}{l}91 \cdot 04 \\
(7 \cdot 16)\end{array}$ \\
\hline $\begin{array}{c}\text { FEF }_{25-75} \\
(\% \mathrm{pr})\end{array}$ & $\begin{array}{c}70 \cdot 13 \\
(24 \cdot 13)\end{array}$ & $\begin{array}{c}60 \cdot 21 \\
(19 \cdot 66)\end{array}$ & $\begin{array}{c}80 \cdot 22 \\
(27.65)\end{array}$ & $\begin{array}{l}66.57 \\
(21.82)\end{array}$ \\
\hline $\begin{array}{c}\text { FEF }_{75-85} \\
(\% \mathrm{pr})\end{array}$ & $\begin{array}{c}74.05 \\
(34 \cdot 24)\end{array}$ & $\begin{array}{c}59 \cdot 56 \\
(28.91)\end{array}$ & $\begin{array}{c}79 \cdot 58 \\
(34 \cdot 86)\end{array}$ & $\begin{array}{l}67 \cdot 39 \\
(25 \cdot 68)\end{array}$ \\
\hline $\begin{array}{l}\mathrm{TLCO}_{\mathrm{sb}} \\
\text { (\% pr) } \\
\mathrm{KCO}(\% \mathrm{pr}) \\
\text { FuCO (\% pr) }\end{array}$ & $\begin{array}{l}118.67 \\
(24.95) \\
103 \cdot 15 \\
(17 \cdot 11) \\
100 \cdot 50 \\
(9 \cdot 42)\end{array}$ & $\begin{array}{c}105 \cdot 69 \\
(18 \cdot 87) \\
99 \cdot 22 \\
(14 \cdot 14) \\
94 \cdot 87 \\
(9 \cdot 81)\end{array}$ & $\begin{array}{l}117.95 \\
(11.95) \\
106.97 \\
(15.60) \\
96.85 \\
(31.59)\end{array}$ & $\begin{array}{l}106 \cdot 46 \\
(19 \cdot 89) \\
101 \cdot 72 \\
(18 \cdot 12) \\
97 \cdot 99 \\
(21 \cdot 37)\end{array}$ \\
\hline $\begin{array}{l}\text { FuaCO } \\
\text { (\% pr) }\end{array}$ & $\begin{array}{l}90 \cdot 78 \\
(7.89)\end{array}$ & $\begin{array}{c}88.64 \\
(10 \cdot 12)\end{array}$ & $\begin{array}{c}82.86 \\
(26.97)\end{array}$ & $\begin{array}{c}87.73 \\
(11.09)\end{array}$ \\
\hline $\begin{array}{l}\mathrm{TLCO}_{\text {(\% }} \\
(\% \mathrm{pr}) \\
\triangle \mathrm{N} 2(\% \mathrm{pr})\end{array}$ & $\begin{array}{c}102 \cdot 66 \\
(7 \cdot 89) \\
82 \cdot 84 \\
(41 \cdot 33)\end{array}$ & $\begin{array}{c}83 \cdot 77 \\
(20 \cdot 52) \\
117 \cdot 28 \\
(148 \cdot 58)\end{array}$ & $\begin{array}{c}84 \cdot 17 \\
(37 \cdot 64) \\
70 \cdot 00 \\
(29 \cdot 89)\end{array}$ & $\begin{array}{c}90 \cdot 17 \\
(24.55) \\
120.95 \\
(101.70)\end{array}$ \\
\hline $\begin{array}{r}\text { CV/FVC } \\
\text { (\% pr) }\end{array}$ & $\begin{array}{l}106 \cdot 28 \\
(14 \cdot 72)\end{array}$ & $\begin{array}{c}91 \cdot 56 \\
(56.01)\end{array}$ & $\begin{array}{c}99.71 \\
(53.02)\end{array}$ & $\begin{array}{l}113 \cdot 51 \\
(37 \cdot 10)\end{array}$ \\
\hline
\end{tabular}

Comparisons are made between exposed normal and abnormal CR using appropriate paired $t$ test $\left({ }^{*} p<0.05\right)$. 
radiographic abnormalities when compared with subjects with normal radiographs, and all the indices of carbon monoxide tests in group 1 were lower in subjects with an abnormal radiograph compared with those with a normal chest radiograph.

\section{Discussion}

There have been many case reports of pulmonary fibrosis among hard metal workers. ${ }^{11-22}$ The occupational origin of lung fibrosis among hard metal workers is assessed in most publications on few observations (less than 10 cases). The disease may appear after six months to two years of exposure but it is not uncommon to observe the disease only after 20 to 25 years and the pathogenesis is still incompletely understood. Ruttner, who reported ten cases of pulmonary fibrosis confirmed by histological examination, concluded that the fibrosis observed in hard metal workers has no unusual features. ${ }^{23}$ There is general agreement on the clinical aspects: dry and irritative cough characterise the first stage. ${ }^{1120}$ Asthma may be observed in atopic or non-atopic subjects ${ }^{24}$ and is another aspect of the disease. Asthma is associated with cough and sputum and the attacks occur towards the end or after the workshift. These attacks do not occur during the weekend or during holidays. Symptoms reappear typically one or two days after return to work.

Diffuse interstitial pulmonary fibrosis is the most severe form. It may rapidly lead to respiratory insufficiency, even after exposure has ceased. Individual factors probably play a major part; many workers are exposed to the hazards whereas only some develop the disease. ${ }^{192024}$ According to Coates and Watson, these features are similar to those of a hypersensitivity pneumonitis. ${ }^{25}$ Allergic mechanisms are frequently suspected ${ }^{141526}$ and sometimes related to individual capacity for absorbing the metal. ${ }^{24}$ But which metal is responsible? Arguments for a causal role for cobalt dust were given by observations of pulmonary fibrosis among diamond polishers or grinders, using tools made with diamond cemented on a cobalt support without any tungsten carbide ${ }^{27}$ and by experimental observations of pulmonary fibrosis in animals exposed to cobalt dusts, whereas tungsten carbide dust does not give the same results. ${ }^{28}$ On the other hand, clinical symptoms described among cobalt workers are similar to those observed in hard metal workers $^{29-32}$; the common element in these two activities is cobalt dust.

Is it, perhaps, more appropriate to speak about "cobalt pneumonitis" due to an allergic phenomenon rather than hard metal disease? The fibrosis observed has no particular characteristics and it may regress after corticosteroids or by removal from exposure at an early stage. ${ }^{11} 12182933$

Our cross sectional study concerned another aspect of the problem-that is, the clinical and functional respiratory disturbances among hard metal workers at work. There has been no significant change in the manpower of these three factories during the past two years; the workers do not leave work because of high unemployment. Cough or sputum, or both, were slightly more frequent in exposed groups than in controls, particularly among the non-smokers, but the percentage of chronic bronchitis observed in this study was far lower than the $11 \%$ quoted by Kusaka ${ }^{34}$ in 247 exposed workers. "Irritative" respiratory symptoms (dry cough, blocked nose ...) were rare (observed in $10 \%$ exposed or non-exposed workers) compared with the $40 \%$ observed by Huez. ${ }^{18}$ In the study by Baudoin et al 15 of the 100 exposed workers had irritative symptoms related to work." Five of these 15 developed a pulmonary fibrosis six months to four years later. Frequency of asthma, allergy, and rhinopharyngeal symptoms were similar in exposed and control groups.

Radiological abnormalities were more frequently observed in exposed workers, particularly in those of group 1 (soft carbide), which leads us to suspect that a risk of pulmonary fibrosis may exist even in apparently healthy workers. This was supported by lower values of VC, $\mathrm{FEV}_{1}$, and of carbon monoxide indices in exposed workers with abnormal pulmonary radiographs compared with those with normal radiographs. In a study by Sprince et al (presented at XXIst Congress on Occupational Health, Dublin, 1984) on 198 workers exposed to hard metal dust five of the $75(6.8 \%)$ non-smokers had radiographic shadows suggestive of interstitial disease. One had a restrictive syndrome and three had a low value of $\mathrm{TCO}_{\mathrm{sb}}$.

Carbon monoxide transfer tests in our study showed significantly lower values of $\mathrm{FuCO}$ and $\mathrm{TCO}_{\mathrm{ss}}$ in exposed non-smoker workers, compared with controls. The same differences were observed in smokers but were less significant. These results are in agreement with those of Meyer $e t a l^{20}$ and Baudouin et al ${ }^{11}$ who observed low CO transfer values in hard metal workers with fibrosis.

Concerning the occupational exposure, our results are in agreement with the reports relating pathological observations among workers engaged in finishing work, ${ }^{35}$ usually considered to be less dangerous. In particular, clinical and functional differences were observed between women of groups 1 and 2, whereas no difference was observed between those of group 1 and the controls.

The results of this study on $\mathbf{4 2 5}$ workers exposed to hard metal dust in three factories show that pulmonary symptoms and functional abnormalities are relatively mild. This may explain why most publications concern individual case reports. On the other hand, abnormalities of pulmonary radiographs associated with functional disturbances more often 
observed in exposed workers seem to suggest that some risk of fibrosis may exist and may be more frequent than previously suspected in asymptomatic subjects.

The early diagnosis of pulmonary damage is important because of its presumed reversibility at this stage. It implies more frequent surveys than those stipulated by French law, including pulmonary radiograph and respiratory function tests (the most important being the CO transfer test). The measurement of cobalt in the urine, ${ }^{16-1836}$ may be an index for occupational exposure to hard metal dust and cobalt.

This work was achieved with contributions from Drs D Fichet, L Martin, J Moline, F Pellet, F Perdrix, A Rosmorduc, and A Tomas, and the technical help of V Baudin, M Betz, and J P Toamain. We thank Mrs A Croquin and Mrs C Cericola for typing the manuscript and drawing the figures.

Requests for reprints to Dr C Meyer-Bisch, INRS, Avenue de Bourgogne, BP 27, F54501 Vandoeuvre Cedex.

\section{References}

1 Bates DV, Macklem PT, Christie RV. Respiratory function in disease. 2nd ed. Philadelphia: WB Saunders, 1971.

2 Buist AS, Ross BB. Predicted values for closing volume using modified single breath nitrogen test. Am Rev Respir Dis 1973;107:744-52.

3 Cotes JE, Hall AM. The transfer factor for the lung; normal values in adults. In: Arcangeli A, Cotes JE, Cournand A, et al, eds. Introduction to the definition on normal values for respiratory function in man. Milano: Pan Minerva Medica, 1970:327-43.

4 American Thoracic Society. Snowbird workshop on standardisation of spirometry. Am Rev Respir Dis 1979;119:831-8.

5 Morris JF, Koski A, Breese JO. Normal values and evaluation of forced end-expiratory flow. Am Rev Respir Dis 1975;111: 755-62.

6 International Labour Office. ILO international classification of radiographs of the pneumoconioses. Geneva: ILO, 1980.

7 Peltier A, Demange M. Exposition aux poussières de métaux durs. Cahiers de Notes Documentaires 1982;108:359-65.

8 Fletcher CM. Causes and development of chronic airways obstruction and its further investigation. Bull Eur Physiopathol Respir 1973;9:1131-48.

9 American Thoracic Society. Definitions and classification of chronic bronchitis, asthma, and pulmonary emphysema. Am Rev Respir Dis 1962;85:762-8.

10 Snedecor GW, Cochran WG. Statistical methods. 6th ed. Ames, Iowa: Iowa State University Press, 1976:400.

11 Baudouin J, Jobard P, Moline J, et al. Les troubles pulmonaires observés chez les ouvriers de l'industrie des métaux durs. Rev Fr Mal Respir 1975;3:343-62.

12 Blanc M, Barral-Chamaillard C. Pneumoconiose par exposition au carbure de tungstène. Nouvelle Presse Medicale 1978;7: 2656-7.

13 Desoille H, Brouet G, Assouly M, Liot F, Brechtel P. Fibrose pulmonaire diffuse chez un sujet exposé aux poussières de cobalt et de carbure de tungstêne. Archives des Maladies Professionelles de Médecine du Travail et de Securité Sociale 1962;23:570-8.

14 Forrest ME, Skerker LB, Nemiroff MJ. Hard metal pneumoconiosis: another cause of diffuse interstitial fibrosis. Radiology 1978;128:609-12.

15 Hartmann A, Wüthrich B, Bolognini G. Berufsbedingte Lungenk- rankheiten bei der Hartmetallproduktion und-bearbeitung. Ein Allergisches Geschehen? Schweiz Med Wochenschr 1982;112: 1137-41.

16 Hartung M, Valentin $H$. Lungen fibrosen durch Hartmetallstäube. Zentralblatt für Bakteriologie Microbiologie und HygieneErste Abt Originale B 1983;177:237-50.

17 Hartung $M$, Valentin H. Die inhalative Cobalt-Belastung. Eine möglische Ursache der Hartmetallfibrose der Lunge. In: Proceedings of the VIth international pneumoconiosis conference, Bochum, 1983. Bochum: ILO, 1984:168-75.

18 Huez D. Pneumoconioses aux poussières de métaux durs: rôle du cobalt. Importance de la prévention. Tours: Thèse Médecine, 1977.

19 Kitamura H, Kitamura H, Tozawa T, Kimula Y. Cemented tungsten carbide pneumoconiosis. Acta Pathol Jpn 1978; 28:921-35.

20 Meyer PD, Stoeckel C, Geist T, Le Bouffant L, Roegel E. A propos de trois nouveaux cas de fibrose pulmonaire chez des affûteurs d'outils renforcés au carbure de tungstène. Poumon-Coeur 1981;37:165-75.

21 Teyssier L, Guerin L, Frey N, Lesobre R. Fibrose pulmonaire observée dans l'industrie des métaux durs. Archives des Maladies Professionelles de Médecine du Travail et de Securité Sociale 1975;36:53-6.

22 Yokoyama K, Kusaka Y, Yamamoto S, Sera Y. A case of interstitial pneumonitis due to hard metal (stellite). Nikkyo Shikkai Shi 1983;21:1096-1100.

23 Ruttner JR. The pathology of the "hard metal lung". In: Proceedings of the VIth international pneumoconiosis conference, Bochum, 1983. Bochum: ILO, 1984:149-58.

24 Sjögren I, Hillerdal G, Andersson A, Zetterström O. Hard metal lung disease: importance of cobalt in coolants. Thorax 1980; 35:653-9.

25 Coates EO, Watson JHL. Pathology of the lung in tungsten carbide workers using light and electron microscopy. J Occup Med 1973;15:280-6.

26 Davison AG, Haslam PL, Corrin B, et al. Interstitial lung disease and asthma in hard metal workers: bronchoalveolar lavage, ultrastructural, and analytical findings and results of bronchial provocation test. Thorax 1983;38:119-28.

27 Demedts M, Gheysens B, Nagels J, Verbeken E, Lauweryns J, Van Den Eeckhout A. Cobalt lung in diamond polishers. Am Rev Respir Dis 1984;130:130-5.

28 Brooks SM. Lung disorders resulting from the inhalation of metals. Clinics in Chest Medicine 1981;2:235-54.

29 Pelletier A, Leroy MJF, Oswald T, et al. Pneumopathie interstitielle diffuse liée au carbure de tungstène confirmée par lavage broncho-alvéolaire, régressive sous corticothérapie. Rev Pneumol Clin 1984;40:131-4.

30 Von Reinl W, Schnellbächer F, Rahm G. Lungenfibrosen und entzündliche Lungenerkrankungen nach Einwirkung von Kobaltkontaktmasse. Zentralblatt für Arbeitzmedizin Albeitsschutz und Prophylaxe 1979;12:318-25.

31 Scansetti G, Lamon S, Botta GC, Talarico S, Piolatto G. Valutazione dell'esposizione a cobalto nella produzione di metalli duri con misure ambientali e biologiche. Med Lav 1983;74:323-32.

32 Scherrer M, Maillard JM. Hartmetall-Pneumopathien. Schweiz Med Wocheuschr 1982;112:198-207.

33 Hartung $M$, Schaller K-H, Brand $E$. On the question of the pathogenic importance of cobalt for hard metal fibrosis of the lung. Int Arch Occup Environ Health 1982;50:53-7.

34 Kusaka Y, Sugimoto K, Seki Y, et al. Bronchopulmonary diseases due to the hard metal dust. Viewpoint of clinical examinations. Jpn J Ind Health 1982;24:636-48.

35 Kusaka Y, Ichikawa Y, Shirakawa T, Goto S. Effect of hard metal dust on ventilatory function. Br J Ind Med 1986;43:486-9.

36 Perdrix A, Pellet F, Vincent M, De Gaudemaris R, Mallion JM. Cobalturie comme traceur de l'exposition aux carbures métalliques frittés. In: Proceedings of the VIth international pneumoconiosis conference, Bochum, 1983. Bochum: ILO, 1984:1176-90. 